\title{
Strategic sourcing in the UK bioenergy industry
}

\author{
James A. Scott, William Ho*, and Prasanta K. Dey
}

Operations and Information Management Group

Aston Business School, Aston University

Birmingham B4 7ET, United Kingdom

*E-mail: w.ho@aston.ac.uk

\begin{abstract}
Successful supply chain management requires the management of a complex, multistakeholder, multi-criteria system. Stakeholder inclusion in the supply chain design and decision making processes is an area of growing interest for companies looking to design sustainable supply chains or produce sustainable products. This paper demonstrates the use of the integrated quality function deployment and analytic hierarchy process (QFD-AHP) method for the inclusion of a wide group of stakeholder requirements into the supplier selection process. The method provides a weighted ranked list of evaluating criteria which can be used to assess potential suppliers in the UK renewable bioenergy industry. The bioenergy industry is suitable as there are many stakeholders placing various requirements upon potential biomass suppliers. The paper uses a mixture of literature review and semistructured industry interviews to answer three research questions: which stakeholder groups are important when selecting biomass suppliers for the UK? What requirements are made by these stakeholders on the supply of biomass fuels and feedstocks? Which evaluating criteria are most important?
\end{abstract}

Keywords: Bioenergy; Strategic sourcing; Multi-stakeholder; Multi-criteria; Quality function deployment; Analytic hierarchy process.

*Corresponding author 


\section{Introduction}

The UK has backed bioenergy or energy from biomass as a major contributor to realizing various carbon reduction commitments (DECC, 2009). Although there is scope for targets to be reached using various low carbon and renewable technologies, biomass has great potential given the technology is well understood and the finances and structure of schemes are similar to traditional combustion power stations. In addition to combustion conversion technologies, several advanced conversion technologies are becoming commercially available as interest in biomass and bioenergy increases. Gasification and pyrolysis as well as anaerobic digestion attract significant government incentives for the production of gas, electricity and heat. The result is an expected surge in the demand for biomass resources (DECC, 2009).

Biomass appears from a wide variety of sources ranging from those usually considered waste products, such as municipal waste or treated sewage waste and agricultural arisings, biproducts and commercial organic waste streams through to woody biomass or energy grasses specifically grown for energy conversion (E4tech, 2009; AEA et al., 2011). Biomass for energy schemes also tends to operate best at the low value end of the biomass scale. Whilst a broad oak tree can make a fine house or a straight pine can make a table top, rice husks, olive pits, branches from thinning's, food waste, leaves and bark are more difficult to find viable value adding processes for. Conversion to bioenergy can offer added value for these materials diverting them from waste streams. It is therefore likely that the UK will see a sharp and dramatic increase in the use of biomass for energy in various guises including international imports.

As with most energy resources and technologies, bioenergy is not without controversy, the carbon-reduction and sustainability credentials of these materials have come under scrutiny along with the rising interest from government and investors. These issues are recognized in EU legislation on sustainability for biomass which has been mandated by the UK at the time of writing. The sustainability assurance certificate process is split into two main sections, firstly the carbon emissions impact of the material, and secondly the change in land use criteria. However, there are many requirements made of biomass supply chains and suppliers over and above the sustainability assurance certificate, additionally they are made by a variety of parties with influence over the long-term success of a bioenergy facility.

Supplier selection for biomass schemes is a multi-stakeholder, multi-criteria system that is very sensitive to sustainability issues. The incorrect choice of supplier can lead to an unsustainable system, for instance, refusal of project finance, unreliable operation of the 
bioenergy plant, depletion or failure of fuel supply, and extensive environmental damage through deforestation and greenhouse gas emissions. To ensure successful supplier selection in this complex industry, this paper uses a mixture of literature review and semi-structured interviews to identify the concerned stakeholder groups, their requirements, and evaluating criteria from a UK perspective. An integrated quality function deployment and analytic hierarchy process (QFD-AHP) method is then applied to quantify their interrelationships and measure their importance ratings based on a real case of the bioenergy development company located in Birmingham, UK.

There are three research questions addressed by this paper. Firstly, which stakeholder groups are important when selecting biomass suppliers for the UK? Secondly, what requirements are made by these stakeholders on the supply of biomass fuels and feedstocks? Thirdly, which evaluating criteria are most important? The contribution of this research is to demonstrate the application of the QFD-AHP method for incorporating stakeholder opinions into the supplier selection process for bioenergy schemes in the UK. The paper also identifies the specific supplier evaluating criteria used by stakeholders when assessing supplier suitability.

This paper is organized as follows. Section 2 reviews the literature concerning the current practice in sourcing and managing biomass suppliers as well as theoretical background to supplier selection and the management of stakeholder requirements. Section 3 describes the QFD-AHP method in a step-by-step approach. Section 4 applies the method for the biomass supplier selection in the UK bioenergy industry. Section 5 discusses the findings, whereas Section 6 concludes the paper.

\section{Literature review}

According to Prajogo et al. (2012) and others, including Narasimhan et al. (2001) and Talluri and Sarkis (2002), supplier assessment and performance measurement is a key part of supply chain management. They also explain that as competition has moved from a firm level to a supply chain level, suppliers have become important to the performance of the buying firm. Huang and Keskar (2007) discuss the importance of formalizing this supplier assessment using performance metrics as well as aligning the supplier selection process with business strategy and product life-cycle stage. Elsewhere in the theoretical literature the discussion between taking a resource based view and a relational view is influencing the way that suppliers are assessed, selected and managed. These theoretical ideas are directly relevant to the management of biomass supply chains, however, perhaps due to the 
immaturity of the biomass for energy industry sector biomass has not been fully discussed in these terms. Rather managers have attempted to extend practices from other areas such as solid energy procurement such as coal or oil or practices from the forestry industry have been extended.

These more established industries have been well studied in the literature as documented by D’Amours et al. (2008) for the pulpwood industry although the case study by Koskinen (2009) finds that supply chain management practices are not fully integrated with the procurement process of a large paper manufacturer. This is supported by a further case study by Carlsson and Rönnqvist (2005) which illustrates how operational management modelling assisted with the logistics design and customer integration at a large wood products company in Europe. Waste resources have attracted less attention regarding its strategic procurement as would be expected given that it has traditionally not been viewed as a product for procurement. However, the area of waste combustion is well studied from a technical and life-cycle perspective, most relevantly by Fruergaard and Astrup (2011) and Burnley et al. (2011) as are the collection and logistics of waste management (Haastrup, 1998; Caputo et al., 2003; Skovgaard et al., 2005; Longden et al., 2007; Beigl et al., 2008; Karagiannidis et al., 2009; Cheng and Hu, 2010; Iakovou et al., 2010).

de Brito et al. (2008) provide an interesting review on the progress of sustainable supply chain management and focus on the fashion industry. The paper identified two major themes of sustainable supply chain management, firstly supplier management for risks and performance, and secondly supply chain management for 'sustainable' products. The bioenergy industry is an interesting case as at first inspection it appears to be about producing a 'sustainable' product, electricity, heat or transport fuel. However, in order to produce this sustainable product, it is the management of risks and performance of the supply chain which must be done in a sustainable way. de Brito et al. (2008) also identify that pressures and incentives for sustainability in supply chains come from a variety of sources, namely legal demands, customer demands, responses to stakeholders, competitive advantage, environmental and social pressure groups, and fear of reputation loss. Also, in the fashion industry, Caniato et al. (2012) discuss the "influence of stakeholder pressures on the adoption of environmental practices” referencing Ciliberti et al. (2008) and Sarkis et al. (2010). These pressures are also seen in the solid bioenergy industry where practitioners are keen to avoid the controversy which has surrounded the use and production of biofuel, this has been extensively discussed for the UK (Chalmers and Archer, 2011; Upham et al., 2011; Boucher, 2012). 
Considering this importance of stakeholder requirements in setting the tone for sustainable supply chains and their influence on company performance along with the growing importance of supply chain management to company competitiveness, a question remains about how stakeholder requirements regarding sustainability, or other salient areas, can be incorporated into supply chain management processes. This paper contributes to this section of the literature by demonstrating a method of supplier selection that incorporates a blend of stakeholder requirements to generate a decision that can be considered as holistically successful as possible considering all stakeholders. The aim of the presented method is not to select the supplier that would be considered most sustainable, but rather to find a supplier that best meets the requirements of the wider stakeholder group, this may include sustainability requirements but the aim is to show how the most holistically successful supplier can be selected. The paper also documents the criteria used by stakeholders to evaluate the suitability of particular suppliers.

The QFD-AHP method has been applied previously in several studies (Ho, 2008; Ho et al., 2011). The most popular application of the QFD-AHP method was found to be for manufacturing decision making especially for product design selection (Wang et al., 1998; Hsiao, 2002; Kwong and Bai, 2002; Madu et al., 2002; Kwong and Bai, 2003; Myint, 2003); Higher education (Köksal and Eğitman, 1998; Lam and Zhao, 1998) and logistics (Chuang, 2001; Partovi, 2006). To our best knowledge, the QFD-AHP method has not been applied in the bioenergy industry (Ho, 2008; Ho et al., 2010; Scott et al., 2012).

\section{Methodology}

To better align supplier selection (and sourcing strategy) with corporate/business strategy, the QFD-AHP method is developed. The QFD is used for various stakeholders to express their requirements, and also to translate the conceptual stakeholder requirements into multiple comparable evaluating criteria for supplier selection, which are used to benchmark the suppliers. The most important information that the QFD provides is the weights of evaluating criteria, which are derived by the importance ratings of stakeholder requirements together with the relationship weightings between stakeholder requirements and evaluating criteria. Generally, both importance ratings of stakeholder requirements and relationship weightings are determined by the decision makers arbitrarily. This may result in a certain degree of inconsistency, and therefore degrade the quality of decisions made. To overcome this drawback, the AHP is used to evaluate them consistently. To summarize, the QFD-AHP method ensures successful strategic sourcing because the supplier selected can satisfy the 
majority of the conflicting requirements raised by the key stakeholders across the bioenergy supply chain in the UK.

The QFD-AHP method is described in the following steps (Fig 1). The method comprises of series of two houses of quality (HOQ), which is a tool of QFD. Each of HOQ1 (refer to steps 1 to 5) and HOQ2 (refer to steps 6 to 9) has an interrelationship matrix. These matrices are completed using the AHP. This process allows different stakeholder groups to express and rank their requirements in HOQ1, and then assess the importance of various evaluating criteria in terms of fulfilling the stakeholder requirements in HOQ2. The importance weightings of evaluating criteria could be used to benchmark and select the strategic biomass suppliers in the bioenergy industry.

Step 1: $\quad$ Identify the stakeholder groups.

Step 2: Determine the importance rating of each stakeholder group in terms of the influence over the project.

Step 3: Identify the stakeholder requirements.

Step 4: Determine the relationship weights between the stakeholder groups and stakeholder requirements using AHP (steps 4.1 to 4.7).

Step 4.1: $\quad$ AHP pairwise comparison

Construct a pairwise comparison matrix,

$$
A=\left[\begin{array}{cccc}
a_{11} & a_{12} & \cdots & a_{1 n} \\
a_{21} & a_{22} & \cdots & a_{2 n} \\
\vdots & \vdots & \ddots & \vdots \\
a_{n 1} & a_{n 2} & \cdots & a_{n n}
\end{array}\right],
$$

where $n$ denotes the number of elements (stakeholder requirements in HOQ1), and $a_{i j}$ refers to the comparison of element $i$ to element $j$ with respect to each criterion (stakeholder groups in HOQ1). The 9-point scale, shown in Table 1, can be used to decide on which element is more important and by how much.

\section{Step 4.2: $\quad$ AHP synthesization}

Divide each entry $\left(a_{i j}\right)$ in each column of matrix $A$ by its column total. The matrix now becomes a normalized pairwise comparison matrix, 


$$
A^{\prime}=\left[\begin{array}{cccc}
\frac{a_{11}}{\sum_{i \in R} a_{i 1}} & \frac{a_{12}}{\sum_{i \in R} a_{i 2}} & \cdots & \frac{a_{1 n}}{\sum_{i \in R} a_{i n}} \\
\frac{a_{21}}{\sum_{i \in R} a_{i 1}} & \frac{a_{22}}{\sum_{i \in R} a_{i 2}} & \cdots & \frac{a_{2 n}}{\sum_{i \in R} a_{i n}} \\
\vdots & \vdots & \ddots & \vdots \\
\frac{a_{n 1}}{\sum_{i \in R} a_{i 1}} & \frac{a_{n 2}}{\sum_{i \in R} a_{i 2}} & \cdots & \frac{a_{n n}}{\sum_{i \in R} a_{i n}}
\end{array}\right],
$$

where $R$ denotes the set of stakeholder requirements, that is, $R=\{1$, $2, \ldots, n\}$.

Step 4.3: Compute the average of the entries in each row of matrix $A^{\prime}$ to yield column vector,

$$
C=\left[\begin{array}{c}
c_{1 k}^{1} \\
\vdots \\
c_{n k}^{1}
\end{array}\right]=\left[\begin{array}{l}
\frac{\left(\frac{a_{11}}{\sum_{i \in R} a_{i 1}}+\frac{a_{12}}{\sum_{i \in R} a_{i 2}}+\cdots+\frac{a_{1 n}}{\sum_{i \in R} a_{i n}}\right)}{n} \\
\vdots \\
\left(\frac{a_{n 1}}{\sum_{i \in R} a_{i 1}}+\frac{a_{n 2}}{\sum_{i \in R} a_{i 2}}+\cdots+\frac{a_{n n}}{\sum_{i \in R} a_{i n}}\right) \\
n
\end{array}\right],
$$

where $c_{i k}^{1}$ denotes the relationship weightings between stakeholder requirement $i$ and its corresponding stakeholder group $k$ in HOQ1.

\section{Step 4.4: $\quad$ AHP consistency verification}

Multiply each entry in column $i$ of matrix $A$ by $c_{i k}^{1}$. Then, divide the summation of values in row $i$ by $c_{i k}^{1}$ to yield another column vector,

$$
\bar{C}=\left[\begin{array}{c}
\bar{c}_{1 k}^{1} \\
\vdots \\
\bar{c}_{n k}^{1}
\end{array}\right]=\left[\begin{array}{c}
\frac{c_{1 k}^{1} a_{11}+c_{2 k}^{1} a_{12}+\cdots c_{n k}^{1} a_{1 n}}{c_{1 k}^{1}} \\
\vdots \\
\frac{c_{1 k}^{1} a_{n 1}+c_{2 k}^{1} a_{n 2}+\cdots c_{n k}^{1} a_{n n}}{c_{n k}^{1}}
\end{array}\right],
$$

where $\bar{C}$ refers to a weighted sum vector.

Step 4.5: Compute the averages of values in vector $\bar{C}$ to yield the maximum eigenvalue of matrix $A$, 


$$
\lambda_{\max }=\frac{\sum_{i \in R} \bar{c}_{i k}^{1}}{n} .
$$

Step 4.6: Compute the consistency index,

$$
C I=\frac{\lambda_{\max }-n}{n-1}
$$

Step 4.7: Compute the consistency ratio,

$$
C R=\frac{C I}{R I(n)},
$$

where $R I(n)$ is a random index of which the value is dependent on the value of $n$, shown in Table 2 . If $C R$ is greater than 0.10 , then go to step 4.1. Otherwise, go to step 5.

Step 5: Compute the importance rating of each stakeholder requirement,

$$
w_{i}^{1}=\sum_{k \in S} p_{k} c_{i k}^{1}
$$

where $S$ denotes the set of company stakeholders, that is, $S=\{1,2, \ldots, m\}$, and $p_{k}$ denotes the importance of stakeholder group $k$.

Step 6: Copy the stakeholder requirements (step 3) and their corresponding importance ratings (step 5) into HOQ2.

Step 7: $\quad$ Identify the supplier evaluating criteria.

Step 8: Determine the relationship weightings between evaluating criteria $i$ and its corresponding stakeholder requirements $k, c_{i k}^{2}$, using AHP (steps 4.1 to 4.7). Note that, in HOQ2, $R$ denotes the set of evaluating criteria, that is, $R=\{1,2, \ldots, n\}$, whereas $S$ denotes the set of stakeholder requirements, that is, $S=\{1,2, \ldots, m\}$.

Step 9: Compute the importance rating of each evaluating criterion

$$
w_{i}^{2}=\sum_{k \in S} \bar{w}_{k}^{1} c_{i k}^{2} \text {, }
$$

where $\bar{w}_{k}^{1}$ is computed in step 5 .

\section{Case study: a UK bioenergy development company}

The bioenergy industry in the UK is facing a massive and rapid expansion on the demand side as policies, rising fossil fuel prices and energy demand combine to create favourable conditions for growth. Procuring suitable materials for use as fuel or feedstocks from the available solid biofuels resources is a complex challenge for procurement managers 
working for a bioenergy project development company in Birmingham, UK. Such developer company must find a supply solution that is considered as financially viable, reliable and generally credit worthy in order to secure reasonably priced project finance. However, there are also other stakeholders who hold salience over such project, and developers must also strive to satisfy these diverse requirements. If projects do not meet the requirements of financiers, the projects will not go ahead. Without meeting the requirements of the public, environmental groups and other stakeholders, the project will face opposition and could fail even if planning permission is granted. Any failure at development stage represents a significant cost for developers and causes delays in the delivery of low carbon energy.

The following paragraphs demonstrate the application of proposed method in the company using a step-by-step approach.

\section{Step 1: Identify the stakeholder groups}

The stakeholder groups were derived from the academic literature as shown in Table 3. Semi-structured interviews were then conducted with the identified stakeholder groups. Table 4 shows the semi-structured interview guide containing the key questions or topics that were discussed with every participant. A more free-flowing line of questioning was also used to collect any other relevant information from participants. According to both literature and semi-structured interviews, the six stakeholder groups include financial groups and project partners/investors, environmental groups, developers/operators and utilities, national government and policy makers, local government, and community/public.

\section{Step 2: Determine the importance rating of each stakeholder group}

The importance rating of each stakeholder group was assigned using an order of preference given by the UK bioenergy development company, in which the participants did not complete the pairwise comparison but was able to place the stakeholder groups in order of saliency. A stakeholder with a higher importance rating means that s/he has greater influence over the bioenergy project. Summation of the importance ratings is equal to one.

\section{Step 3: Identify the stakeholder requirements}

In the QFD-AHP method, requirements are a set of desirable characteristics that the final solution should perform well against, in other words, the final solution should as far as possible satisfy the requirements identified by the stakeholders. Through questioning in the semi-structured interviews, several requirements became clear from participant responses. Some requirements were also evident from the grey literature study of UK and EU policy 
documents. The requirements identified are listed in Table 5 along with an explanation of each.

\section{Step 4: Determine the relationship weights between the stakeholder groups and stakeholder requirements using AHP}

To calculate the importance of stakeholder requirements, the relationship weights between the stakeholder groups and their requirements were determined using AHP. For example, the procedure of calculating the relationship weights for finance groups and project partners/investors is to construct a pairwise comparison matrix first as shown in Figure 2. Because four requirements were related to the finance groups and project partners/investors, there were four elements in matrix $A$ only. The relevant requirements were "To offer an attractive business to business contract”, “To provide good contract conditions regarding the supply of fuel”, “To provide material reliably and within the quality specification required”, and "To be financially credible". For synthesization, a normalized comparison matrix is constructed as shown in Figure 3. Based on matrix $A^{\prime}$, a column vector showing the relationship weightings between stakeholder requirements and finance groups and project partners/investors was constructed as shown in Figure 4. To verify the consistency, a weighted sum vector was constructed as shown in Figure 5. Then, the maximum eigenvalue of matrix $A$, consistency index, and consistency ratio were computed as follows.

$$
\begin{aligned}
& \lambda_{\max }=\frac{4.350+4.102+4.069+4.310}{4}=4.208 \\
& C I=\frac{4.208-4}{4-1}=0.069 \\
& C R=\frac{0.069}{0.90}=0.077
\end{aligned}
$$

Because $C R$ was less than 0.10 , the pairwise comparison for the finance groups and project partners/investors was consistent.

\section{Step 5: Compute the importance rating of each stakeholder requirement}

Following the above procedure for determining the relationship weights between the stakeholder requirements and the remaining stakeholder groups, the importance ratings of each stakeholder requirement were computed in HOQ1 as shown in Table 6. 


\section{Step 6: Copy the stakeholder requirements (step 3) and their corresponding importance ratings (step 5) into HOQ2.}

After completing HOQ1, both stakeholder requirements and their corresponding importance ratings were copied into HOQ2, which linked the requirements and evaluating criteria.

\section{Step 7: Identify the supplier evaluating criteria}

Evaluating criteria were identified from academic literature and semi-structured interviews. These criteria had been obtained from mining the interview responses. In many instances, the criteria had been found to overlap with either criteria identified in previous bioenergy literature or in existing literature on supplier selection where such criteria are well studied. The remaining criteria identified in interviews have not been located in previous literature. Table 7 shows which stakeholders identified different criteria along with any corresponding literature sources.

\section{Step 8: Determine the relationship weights between evaluating criteria and its corresponding stakeholder requirements}

Similar to HOQ1, AHP was used to calculate the relationship weightings between the stakeholder requirements and evaluating criteria in HOQ2. Table 8 shows which evaluating criteria are relevant to each requirement. Certainly, the size of each pairwise comparison matrix is varied, and is dependent on the number of evaluating criteria that will achieve a particular requirement. For example, there were four elements in the matrix for the requirement "To offer an attractive business to business contract". They were "Long term contracts”, “Take or pay clauses”, “Track record”, and "Personal relationship”. All of them were related to the requirement.

\section{Step 9: Compute the importance rating of each evaluating criteria}

After determining all relationship weightings between the seven stakeholder requirements and their related evaluating criteria, the importance ratings of each criterion were computed in HOQ2 as shown in Tables 9 to 12. The ten evaluating criteria with the highest and lowest importance rating are shown in Table 13.

\section{Discussions}

\subsection{Discussions of the data}


A larger sample size may have revealed more evaluating criteria or requirements that would be relevant. However, the responses within each stakeholder group were consistent, and in many cases, evaluating criteria identified from interviews has been supported by literature evidence. The policy maker stakeholder group was not available for interview but documentation produced by government departments should make a very suitable proxy for these opinions.

The sample sizes could have been larger had interview data been used from stakeholders interested in a wider variety of projects. The interviews had been taken from stakeholders mainly interested in large scale combustion type projects. The evaluating criteria may well be different for smaller scale projects or projects using other technologies.

As far as possible participants had been asked to give their own opinions from as according to their daily activities or interests in the sector, it is possible that having introduced the research, some participants had manipulated their responses in order to influence the future actions of other stakeholder groups. However, this was considered unlikely given the clear and transparent responses given to interview questions.

\subsection{Discussions of the method}

The QFD-AHP method is rigorous and robust, it produces intuitive results and has a mechanism built in for checking respondent consistency. To complete the entire QFD-AHP method for supplier selection, information must be available regarding each supplier's performance against each evaluating criterion. In a developing market, it is likely that not all of this data will be available to the buyer and they must make some subjective assessment of supplier performance. This is not ideal and if done badly could undermine the advantage of using an analytical approach in the first place.

The method used to identify stakeholder requirements and evaluating criteria was suitable and allowed the participants freedom to talk about aspects they thought were more important and fully think through responses to questions. Most of the evaluating criteria were suggested by more than one stakeholder source or are supported by evidence from literature. Those criteria that are supported could be considered to be more reliable.

\subsection{Discussions of the findings}

From Table 7, the stakeholder groups of "Finance groups" and "Developers/Operators" had similarly aligned interests, both requiring favourable contractual conditions, quality and 
financial credibility. This may reflect the way that operators and developers have aligned their interests with the finance sector as they seek to attract investment. This was mentioned by one participant from the finance stakeholder group "Anyone other than the major utilities has to project finance. Projects are too big for most companies to do on balance sheet.” Even if a project were to be entirely equity funded by some large utility it is likely that similar requirements would be made on suppliers. These contracts and the conditions between them appear critical to the successful operation and development of bioenergy schemes. They are at the centre of a finance deal between investors and developers, without suitable suppliers in place it is unlikely that affordable investment will be forthcoming. However, a conflict then can appear as suppliers are unwilling to be fixed into contracts for long periods when as one participant from the finance stakeholder group stated: "Everybody thinks this is going to take off, so why would you want to lock in for 15 years if it turns out you're locked in at the wrong price?”.

The insistence of financial stability, credibility, track record and fixed prices is also likely to lead to the exclusion of major parts of the biomass market. By requiring well established blue collar type businesses smaller, less affluent suppliers are disadvantaged. These smaller suppliers may be able to provide many of the other attributes required at and would be attractive were these finance related requirements not being made, they may also hold a majority of the available regional biomass resource. When reflecting on this one developer mentioned that "there is really quite a small group of very large global suppliers that are properly suitable against these criteria, in reality we need to do business with smaller companies”. Whilst this is true of waste materials which may be largely controlled by the animal feed industries forestry is slightly different as one participant from the finance stakeholder group pointed out "US forestry ownership is dominated by pension funds and large scale investors so balance sheet strength is pretty good there.”

Energy security is shown as a fringe requirement in this process, only mentioned by central government reports. In reality this issue is seen as important by developers and operators, however this group is more likely to protect themselves from material supply failure using commercial contracts than changing the source location of materials. There is a heavy reliance on the nature and favourability of contracts between buyers and suppliers in the bioenergy industry, this is evident from the results and from qualitative data from the interviews. 
Five of the six stakeholder groups identified environmental impact as an important requirement. Environmental related evaluating criteria feature heavily in the supplier selection lists. The most commonly referenced criterion is the $\mathrm{CO}_{2}$ emissions per $\mathrm{MWh}$ of energy being delivered. This criterion, along with land use change, forms the EU sustainability standard against which biomass suppliers can be measured and found to be compliant or otherwise. 'Performance against EU sustainability standard' is included as a separate criterion as it appeared as such in the interview data. The UK is one of the only countries in the world to have implemented biomass sustainability requirement legislation. However, this attempt to partly commoditize and set a base-standard for sustainability has eventually resulted in further uncertainty for the market due a recent UK report which suggested that the standards for sustainability regarding solid biomass should be "tightened" (CCC, 2011). Therefore, developers are seeking "Standards that go beyond the sustainability standard” for any material that may be contracted for.

Distance from buyer was found to be of low importance. This reflects the global nature of sourcing biomass for the UK market. Many of the recent waves of proposed UK biomass power stations are located at deep water ports to keep options for importing materials open to those operators. The nature of the business and the scale of on-site storage also mean that distance from supplier to buyer is of less importance as delays can well be tolerated. This is mirrored in the fossil fuel industries where fuels are purchased from around the world on various exchange platforms. From interview data with material buyers of both biomass and fossil fuels, it appears that fossil fuel suppliers are not subject to any of the requirements regarding environmental sustainability, social impact and are also largely not required to have particularly secure financial backgrounds. This may reflect the uncertainty associated with operating in a non-commodity dominated market.

\section{Conclusions}

This study has used a combination of literature review, semi-structured interviews, and the QFD-AHP method to answer three questions related to the problem of supplier selection for the bioenergy industry in the UK. In relation to the first research question posed in this paper, the most important stakeholder groups for the UK bioenergy industry can be covered by six groups: Finance/investors, environmental groups, developers and operators including utilities, national policy makers, local government decision makers and the general public or local community. 
In relation to the second research question, these groups hold a variety of requirements and expectations that they make on the suppliers of biomass materials for bioenergy schemes. These requirements can be summarized into the following categories: Business to business contract conditions, fuel specific contract conditions, fuel quality and reliability, environmental impact, financial credibility, social impact, and security of energy supply.

A mixture of traditional and novel supplier evaluating criteria have been identified as being useful for supplier selection. Many conventional supplier selection criteria are not found to be of importance to bioenergy stakeholders including just-in-time delivery, lead time or health and safety issues. Although these aspects may be important in the biomass supplier selection process they have not been identified explicitly in this research. Using the QFDAHP method along with ranking data from interviews, a real case has been reported on. Here an importance weighting is given to each stakeholder group based on order of importance given during industry interviews. In this case, developers and finance groups are given importance in the decision making process and the financial stability of the supplier is found to be the most important criterion followed by a mixture of social, environmental and economic criteria, including experience, job creation, $\mathrm{CO}_{2}$ emissions per unit of energy, and cost of material.

The contribution of this research is to identify the criteria considered important for sourcing biomass fuels and to suggest a method for incorporating the requirements of a wide stakeholder group into the supplier selection process. By better meeting the requirements of the key stakeholders, rather than just those of the decision maker, a more holistically successful supplier selection can be made. Biomass sourcing and selection is a good example of a multi-stakeholder supply chain and is additionally sensitive to sustainability requirements and is thus a good industry to implement the QFD-AHP supplier selection method which could be extended to other industries and similar supplier selection problems. By identifying the requirements of stakeholders and the related evaluating criteria, suppliers can better understand the needs of purchasers and other stakeholders. This will allow them to better customize their service and product offerings to match these requirements. No previous record of supplier selection criteria exists for the bioenergy industry in the academic literature, also there is no previous attempt to weight any evaluating criteria against the requirements of stakeholders using an analytical method. 


\section{Acknowledgements}

This research forms part of a project funded by the ESRC through the EREBUS (Engaging research for business transformation) cluster in the West Midlands region of the UK. Funding is awarded through a CASE studentship partly funded by a private bioenergy developing company who have not been involved in the design or outcomes of this study. 


\section{References}

Adams, P.W., Hammond, G.P., McManus, M.C., Mezzullo, W.G., 2011. Barriers to and drivers for UK bioenergy development. Renewable and Sustainable Energy Reviews $15,1217-1227$.

AEA, DECC, Economics, O., Research, F., Centre, B.E., 2011. UK and Global Bioenergy Resource, in: DECC (Ed.).

Afgan, N.H., Carvalho, M.G., 2003. Multi-criteria assessment of new and renewable energy power plants. Fuel and Energy Abstracts 44, 102.

Ayoub, N., Martins, R., Wang, K., Seki, H., Naka, Y., 2007. Two levels decision system for efficient planning and implementation of bioenergy production. Energy Conversion and Management 48, 709-723.

Barla, S.B., 2003. A case study of supplier selection for lean supply by using a mathematical model. Logistics Information Management 16, 451-459.

Bayazit, O., 2006. Use of analytic network process in vendor selection decisions. Benchmarking: An International Journal 13, 566-579.

Beck, J., Kempener, R., Cohen, B., Petrie, J., 2008. A complex systems approach to planning, optimization and decision making for energy networks. Energy Policy 36, 2795-2805.

Begić, F., Afgan, N.H., 2007. Sustainability assessment tool for the decision making in selection of energy system - Bosnian case. Energy 32, 1979-1985.

Beigl, P., Lebersorger, S., Salhofer, S., 2008. Modelling municipal solid waste generation: A review. Waste Management 28, 200-214.

Bevilacqua, M., Ciarapica, F.E., Giacchetta, G., 2006. A fuzzy-QFD approach to supplier selection. Journal of Purchasing and Supply Management 12, 14-27.

Bottani, E., Rizzi, A., 2008. An adapted multi-criteria approach to suppliers and products selection - An application oriented to lead-time reduction. International Journal of Production Economics 111, 763-781.

Boucher, P., 2012. The role of controversy, regulation and engineering in UK biofuel development. Energy Policy 42, 148-154.

Braglia, M., Petroni, A., 2000. A quality assurance-oriented methodology for handling tradeoffs in supplier selection. International Journal of Physical Distribution \& Logistics Management 30, 96-112.

BTG, 2008. Sustainability criteria and certification systems. DG TREN - European Commission. 
Buchholz, T., Rametsteiner, E., Volk, T.A., Luzadis, V.A., 2009. Multi criteria analysis for bioenergy systems assessments. Energy Policy 37, 484-495.

Burnley, S., Phillips, R., Coleman, T., Rampling, T., 2011. Energy implications of the thermal recovery of biodegradable municipal waste materials in the United Kingdom. Waste Management 31, 1949-1959.

Caniato, F., Caridi, M., Crippa, L., Moretto, A., 2012. Environmental sustainability in fashion supply chains: An exploratory case based research. International Journal of Production Economics 135, 659-670.

Caputo, A.C., Scacchia, F., Pelagagge, P.M., 2003. Disposal of by-products in olive oil industry : waste-to-energy solutions. Applied Thermal Engineering 23, 197-214.

Carlsson, D., Rönnqvist, M., 2005. Supply chain management in forestry - case studies at Södra Cell AB. European Journal of Operational Research 163, 589-616.

CCC, 2011. Bioenergy review, in: Change, C.o.C. (Ed.).

Çebi, F., Bayraktar, D., 2003. An integrated approach for supplier selection. Logistics Information Management 16, 395-400.

Chalmers, J., Archer, G., 2011. Development of a sustainability reporting scheme for biofuels: A UK case study. Energy Policy 39, 5682-5689.

Chan, F.T.S., 2003. Interactive selection model for supplier selection process: an analytical hierarchy process approach. International Journal of Production Research 41, 35493579.

Chan, F.T.S., Chan, H.K., Ip, R.W.L., Lau, H.C.W., 2007. A decision support system for supplier selection in the airline industry. Proceedings of the Institution of Mechanical Engineers, Part B: Journal of Engineering Manufacture 221, 741-758.

Chen, C.-T., Lin, C.-T., Huang, S.-F., 2006. A fuzzy approach for supplier evaluation and selection in supply chain management. International Journal of Production Economics 102, 289-301.

Chen, Y.M., Huang, P.-N., 2007. Bi-negotiation integrated AHP in suppliers selection. International Journal of Operations \& Production Management 27, 1254-1274.

Cheng, H., Hu, Y.D.O.-D.j.b., 2010. Municipal solid waste (MSW) as a renewable source of energy: current and future practices in China. Bioresource technology 101, 3816-3824.

Choy, K.L., Lee, W.B., 2002. A generic tool for the selection and management of supplier relationships in an outsourced manufacturing environment: the application of case based reasoning. Logistics Information Management 15, 235-253. 
Choy, K.L., Lee, W.B., 2003. A generic supplier management tool for outsourcing manufacturing. Supply Chain Management: An International Journal 8, 140-154.

Choy, K.L., Lee, W.B., Lau, H.C.W., Choy, L.C., 2005. A knowledge-based supplier intelligence retrieval system for outsource manufacturing. Knowledge-Based Systems 18, 1-17.

Chuang, P.-T., 2001. Combining the analytic hierarchy process and quality function deployment for a location decision from a requirement perspective. International Journal of Advanced Manufacturing Technology 18, 842-849.

Ciliberti, F., Pontrandolfo, P., Scozzi, B., 2008. Logistics social responsibility: Standard adoption and practices in Italian companies. International Journal of Production Economics 113, 88-106.

D'Amours, S., Rönnqvist, M., Weintraub, A., 2008. Using operational research for supply chain planning in the forest products industry. INFOR: Information Systems and Operational Research 46, 265-281.

de Brito, M.P., Carbone, V., Blanquart, C.M., 2008. Towards a sustainable fashion retail supply chain in Europe: Organisation and performance. International Journal of Production Economics 114, 534-553.

DECC, 2009. The UK Renewable Energy Strategy 2009.

E4tech, 2009. Biomass supply curves for the UK.

Elghali, L., Clift, R., Sinclair, P., Panoutsou, C., Bauen, A., 2007. Developing a sustainability framework for the assessment of bioenergy systems. Energy Policy 35, 6075-6083.

Fruergaard, T., Astrup, T., 2011. Optimal utilization of waste-to-energy in an LCA perspective. Waste Management 31, 572-582.

FSC, 2012. FSC-UK.org, p. Forestry Stewardship Council website.

Gencer, C., Gürpinar, D., 2007. Analytic network process in supplier selection: A case study in an electronic firm. Applied Mathematical Modelling 31, 2475-2486.

Haastrup, P., 1998. A decision support system for urban waste management. European Journal of Operational Research 109, 330-341.

Haralambopoulos, D.A., Polatidis, H., 2003. Renewable energy projects: structuring a multicriteria group decision-making framework. Renewable Energy 28, 961-973.

Heidrich, O., Harvey, J., Tollin, N., 2009. Stakeholder analysis for industrial waste management systems. Waste Management 29, 965-973.

Ho, W., 2008. Integrated analytic hierarchy process and its applications - A literature review. European Journal of Operational Research 186, 211-228. 
Ho, W., Dey, P., Löckstrom, M., 2011. Strategic sourcing: a combined QFD and AHP approach in manufacturing. Supply Chain Management: An International Journal 16, 446-461.

Ho, W., Xu, X., Dey, P.K., 2010. Multi-criteria decision making approaches for supplier evaluation and selection: A literature review. European Journal of Operational Research 202, 16-24.

Hou, J., Su, D., 2007. EJB-MVC oriented supplier selection system for mass customization. Journal of Manufacturing Technology Management 18, 54-71.

Hsiao, S.-W., 2002. Concurrent design method for developing a new product. International Journal of Industrial Ergonomics 29, 55-41.

Huang, S.H., Keskar, H., 2007. Comprehensive and configurable metrics for supplier selection. International Journal of Production Economics 105, 510-523.

Iakovou, E., Karagiannidis, A., Vlachos, D., Toka, A., Malamakis, A., 2010. Waste biomassto-energy supply chain management: A critical synthesis. Waste Management 30, 1860-1870.

Jovanovic, M., Turanjanin, V., Bakic, V., Pezo, M., Vucicevic, B., 2011. Sustainability estimation of energy system options that use gas and renewable resources for domestic hot water production. Energy 36, 2169-2175.

Kahraman, C., Cebeci, U., Ulukan, Z., 2003. Multi-criteria supplier selection using fuzzy AHP. Logistics Information Management 16, 382-394.

Karagiannidis, A., Wittmaier, M., Langer, S., Bilitewski, B., Malamakis, A., 2009. Thermal processing of waste organic substrates: Developing and applying an integrated framework for feasibility assessment in developing countries. Renewable and Sustainable Energy Reviews 13, 2156-2162.

Kaya, T., Kahraman, C., 2010. Multicriteria renewable energy planning using an integrated fuzzy VIKOR \& AHP methodology: The case of Istanbul. Energy 35, 2517-2527.

Köksal, G., Eğitman, A., 1998. Planning and design of industrial engineering education quality. Computers and Industrial Engineering 35, 639-642.

Koskinen, P., 2009. Supply chain strategy in a global paper manufacturing company: a case study. Industrial Management and Data Systems 109, 34-52.

Kwong, C.K., Bai, H., 2002. A fuzzy AHP approach to the determination of importance weights of customer requirements in quality function deployment, Journal of Intelligent Manufacturing 13, 367-377. 
Kwong, C.K., Bai, H., 2003. Determining the importance weights for the customer requirements in QFD using a fuzzy AHP with an extent analysis approach. IIE Transactions 35, 619-626.

Lam, K., Zhao, X., 1998. An application of quality function deployment to improve the quality of teaching. International Journal of Quality \& Reliability Management 15, 389413.

Liu, F.-H.F., Hai, H.L., 2005. The voting analytic hierarchy process method for selecting supplier. International Journal of Production Economics 97, 308-317.

Liu, J., Ding, F.-Y., Lall, V., 2000. Using data envelopment analysis to compare suppliers for supplier selection and performance improvement. Supply Chain Management: An International Journal 5, 143-150.

Longden, D.M., Brammer, J., Bastin, L., Cooper, N., 2007. Distributed or centralised energyfrom-waste policy? Implications of technology and scale at municipal level. Energy Policy 35, 2622-2634.

Madlener, R., Kowalski, K., Stagl, S., 2007. New ways for the integrated appraisal of national energy scenarios: The case of renewable energy use in Austria. Energy Policy 35, 6060-6074.

Madu, C.N., Kuei, C., Madu, I.E, 2002. A hierarchic metric approach for integration of green issues in manufacturing: A paper recycling application. Journal of Environmental Management 64, 272-261.

Muralidharan, C., Anantharaman, N., Deshmukh, S.G., 2002. A multi-criteria group decision making model for supplier rating. Journal of Supply Chain Management 38, 22-33.

Myint, S., 2003. A framework of an intelligent quality function deployment (IQFD) for discrete assembly environment. Computers and Industrial Engineering 45, 269-283.

Narasimhan, R., Talluri, S., Mendez, D., 2001. Supplier evaluation and rationalization via data envelopment analysis: An empirical examination. Journal of Supply Chain Management 37, 28-37.

Ng, W.L., 2008. An efficient and simple model for multiple criteria supplier selection problem. European Journal of Operational Research 186, 1059-1067.

Partovi, F.Y., 2006. An analytic model for locating facilities strategically. Socio-Economic Planning Sciences 34, 55-41.

Perçin, S., 2006. An application of the integrated AHP-PGP model in supplier selection. Measuring Business Excellence 10, 34-49. 
Prajogo, D., Chowdhury, M., Yeung, A.C.L., Cheng, T.C.E., 2012. The relationship between supplier management and firm's operational performance: A multi-dimensional perspective. International Journal of Production Economics 136, 123-130.

Sarkar, A., Mohapatra, P.K.J., 2006. Evaluation of supplier capability and performance: A method for supply base reduction. Journal of Purchasing and Supply Management 12, 148-163.

Sarkis, J., Gonzalez-Torre, P., Adenso-Diaz, B., 2010. Stakeholder pressure and the adoption of environmental practices: The mediating effect of training. Journal of Operations Management 28, 163-176.

Sarkis, J., Talluri, S., 2002. A model for strategic supplier selection. Journal of Supply Chain Management 38, 18-28.

Scott, J.A., Ho, W., Dey, P.K., 2012. A review of multi-criteria decision-making methods for bioenergy systems. Energy 42, 146-156.

Sevkli, M., Koh, L.S.C., Zaim, S., Demirbag, M., Tatoglu, E., 2007. An application of data envelopment analytic hierachy process for supplier selection: a case study of BEKO in Turkey. International Journal of Production Research 45, 1973-2003.

Skovgaard, M., Moll, S., Moller, A., Larsen, H., 2005. Outlook for waste and material flows, in: EEA (Ed.).

Stidham, M., Simon-Brown, V., 2011. Stakeholder perspectives on converting forest biomass to energy in Oregon, USA. Biomass and Bioenergy 35, 203-213.

Talluri, S., Narasimhan, R., 2004. A methodology for strategic sourcing. European Journal of Operational Research 154, 236-250.

Talluri, S., Sarkis, J., 2002. A model for performance monitoring of suppliers. International Journal of Production Research 40, 4257-4269.

Terrados, J., Almonacid, G., Pérez-Higueras, P., 2009. Proposal for a combined methodology for renewable energy planning. Application to a Spanish region. Renewable and Sustainable Energy Reviews 13, 2022-2030.

Turcksin, L., Macharis, C., Lebeau, K., Boureima, F., Van Mierlo, J., Bram, S., De Ruyck, J., Mertens, L., Jossart, J.-M., Gorissen, L., 2011. A multi-actor multi-criteria framework to assess the stakeholder support for different biofuel options: The case of Belgium. Energy Policy 39, 200-214.

Upham, P., Shackley, S., Waterman, H., 2007. Public and stakeholder perceptions of 2030 bioenergy scenarios for the Yorkshire and Humber region. Energy Policy 35, 44034412. 
Upham, P., Speakman, D., 2007. Stakeholder opinion on constrained 2030 bioenergy scenarios for North West England. Energy Policy 35, 5549-5561.

Upham, P., Tomei, J., Dendler, L., 2011. Governance and legitimacy aspects of the UK biofuel carbon and sustainability reporting system. Energy Policy 39, 2669-2678.

van Dam, J., Junginger, M., 2011. Striving to further harmonization of sustainability criteria for bioenergy in Europe: Recommendations from a stakeholder questionnaire. Energy Policy 39, 4051-4066.

Wang, G., Huang, S.H., Dismukes, J.P., 2004. Product-driven supply chain selection using integrated multi-criteria decision-making methodology. International Journal of Production Economics 91, 1-15.

Wang, G., Huang, S.H., Dismukes, J.P., 2005. Manufacturing supply chain design and evaluation. International Journal of Advanced Manufacturing Technology 25, 93-100.

Wang, H., Xie, M., Goh, T.N., 1998. A comparative study of the prioritization matrix method and the analytic hierarchy process technique in quality function deployment. Total Quality Management 9, 421-430.

Wu, T., Dan, S., Blackhurst, J., Appalla, R., 2007. AIDEA: A methodology for supplier evaluation and selection in a supplier-based manufacturing environment. International Journal of Manufacturing Technology and Management 11, 174-192.

Yang, C.-C., Chen, B.-S., 2006. Supplier selection using combined analytical hierarchy process and grey relational analysis. Journal of Manufacturing Technology Management 17, 926-941.

Zhou, Z., Jiang, H., Qin, L., 2007. Life cycle sustainability assessment of fuels. Fuel 86, 256263. 


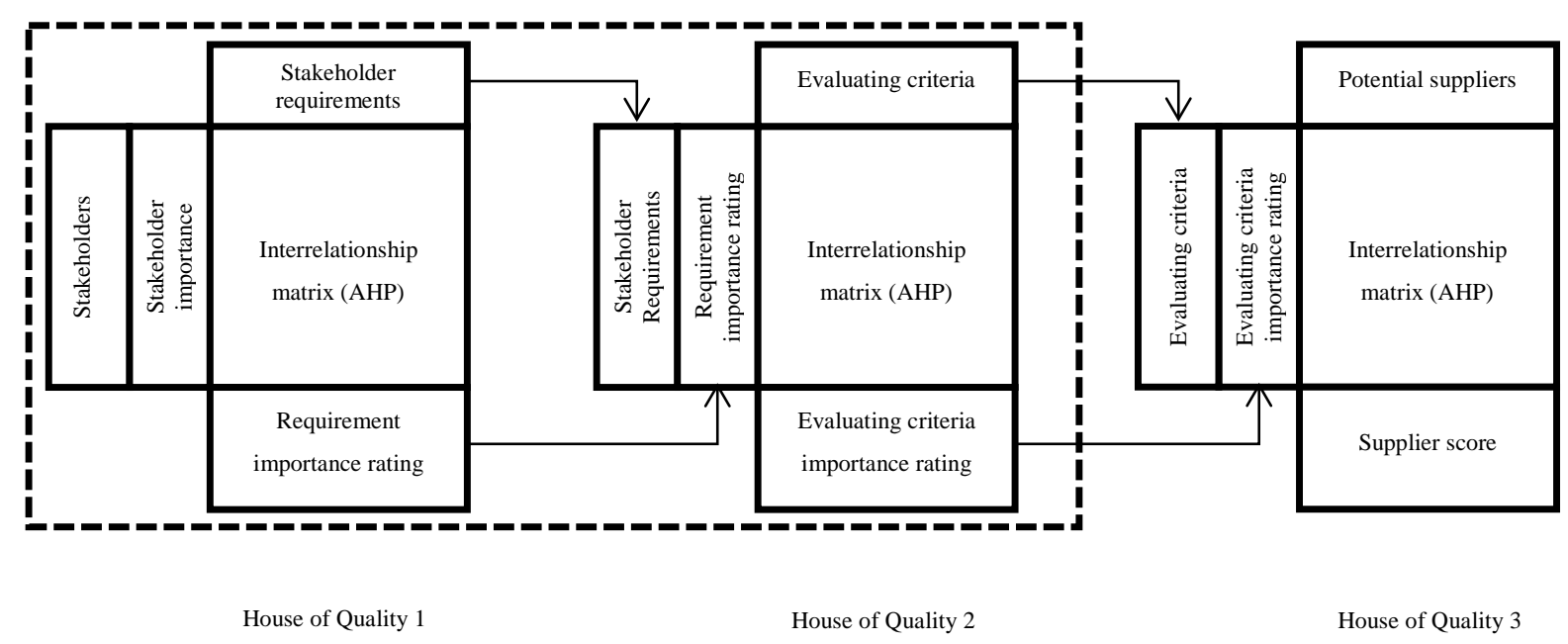

Fig. 1. The QFD-AHP method and data flow.

$$
A=\left[\begin{array}{cccc}
1 & 4 & 5 & 1 / 2 \\
1 / 4 & 1 & 3 & 1 / 3 \\
1 / 5 & 1 / 3 & 1 & 1 / 4 \\
2 & 3 & 4 & 1
\end{array}\right]
$$

Fig. 2. Pairwise comparison matrix.

$$
A^{\prime}=\left[\begin{array}{llll}
0.290 & 0.480 & 0.385 & 0.240 \\
0.072 & 0.120 & 0.231 & 0.160 \\
0.058 & 0.040 & 0.077 & 0.120 \\
0.580 & 0.360 & 0.308 & 0.480
\end{array}\right]
$$

Fig. 3. Normalized pairwise comparison matrix.

$$
C=\left[\begin{array}{l}
0.349 \\
0.146 \\
0.074 \\
0.432
\end{array}\right]
$$

Fig. 4. Column vector.

$$
\bar{C}=\left[\begin{array}{l}
4.350 \\
4.102 \\
4.069 \\
4.310
\end{array}\right]
$$

Fig. 5. Weighted sum vector. 
Table 1

AHP pairwise comparison scale.

\begin{tabular}{|c|c|c|}
\hline Intensity & Importance & Explanation \\
\hline 1 & Equal & Two activities contribute equally to the object \\
\hline 3 & Moderate & Slightly favours one over another \\
\hline 5 & Strong & Strongly favours one over another \\
\hline 7 & Very strong & Dominance of the demonstrated in practice \\
\hline 9 & Extreme & $\begin{array}{l}\text { Evidence favouring one over another of highest possible } \\
\text { order of affirmation }\end{array}$ \\
\hline $2,4,6,8$ & Intermediate & When compromise is needed \\
\hline $\begin{array}{l}\text { Reciprocals of } \\
\text { the above } \\
\text { numbers }\end{array}$ & & For inverse comparison \\
\hline
\end{tabular}

Table 2

List of random index values.

\begin{tabular}{lllllllll}
\hline$n$ & 2 & 3 & 4 & 5 & 6 & 7 & 8 & 9 \\
\hline$R I(n)$ & 0 & 0.58 & 0.90 & 1.12 & 1.24 & 1.32 & 1.41 & 1.45 \\
\hline
\end{tabular}

Table 3

Stakeholders identified within the bioenergy literature.

\section{Bioenergy stakeholder groups Literature sources}

1. Financial groups and project Elghali et al., 2007; Iakovou et al., 2010 partners/investors

2. Environmental groups

Elghali et al., 2007; Upham et al., 2007; Heidrich et al., 2009; Stidham and Simon-Brown, 2011; van Dam and Junginger, 2011

3. Developers/Operators and Utilities

Elghali et al., 2007; Upham et al., 2007; Adams et al., 2011; Stidham and Simon-Brown, 2011; Turcksin et al., 2011; van Dam and Junginger, 2011

4. National government and policy makers

Elghali et al., 2007; Upham et al., 2007; Iakovou et al., 2010; Adams et al., 2011; Stidham and Simon-Brown, 2011; van Dam and Junginger, 2011

5. Local government

Upham et al., 2007; Heidrich et al., 2009; Stidham and Simon-Brown, 2011; Turcksin et al., 2011; van Dam and Junginger, 2011

6. Community/public

Elghali et al., 2007; Stidham and Simon-Brown, 2011 


\section{Table 4}

Semi-structured interview guide.

\begin{tabular}{ll}
\hline Topics & Question prompts \\
\hline 1. Stakeholders & $\begin{array}{l}\text { Which stakeholder groups would you recognize as being } \\
\text { important when selecting biomass suppliers? }\end{array}$ \\
$\begin{array}{l}\text { 2. Stakeholder } \\
\text { requirements }\end{array}$ & $\begin{array}{l}\text { What do you think are the main requirements and motivations } \\
\text { when selecting a supply of biomass for energy? }\end{array}$ \\
3. Evaluating criteria & $\begin{array}{l}\text { When evaluating suppliers, what factors would you look for. If } \\
\text { several can you rank them in importance? }\end{array}$ \\
4. Methods used & $\begin{array}{l}\text { Do you use a specific method or approach already when } \\
\text { selecting or prioritizing Biomass suppliers? }\end{array}$ \\
5. Inadequacies & $\begin{array}{l}\text { Are there any problems you know of with the existing } \\
\text { methods used? Any inadequacies or inefficiencies? }\end{array}$ \\
\hline
\end{tabular}


Table 5

Requirements identified from stakeholder interviews and government documents.

\begin{tabular}{|c|c|c|}
\hline Requirements & $\begin{array}{l}\text { Identifying stakeholder } \\
\text { groups }\end{array}$ & Description of requirements \\
\hline $\begin{array}{l}\text { 1. To offer an } \\
\text { attractive business } \\
\text { to business } \\
\text { contract }\end{array}$ & $\begin{array}{l}\text { Financial groups and project } \\
\text { partners/investors; } \\
\text { Developers/Operators }\end{array}$ & $\begin{array}{l}\text { The potential supplier should be } \\
\text { able to offer a contract which has } \\
\text { attractive clauses and remittances as } \\
\text { well as being an attractive company } \\
\text { to work with. }\end{array}$ \\
\hline $\begin{array}{l}\text { 2. To provide good } \\
\text { contract } \\
\text { conditions } \\
\text { regarding the } \\
\text { supply of fuel }\end{array}$ & $\begin{array}{l}\text { Financial groups and project } \\
\text { partners/investors; } \\
\text { Developers/Operators }\end{array}$ & $\begin{array}{l}\text { The potential supplier should be } \\
\text { able to offer a contract which has } \\
\text { attractive terms regarding the } \\
\text { quality and provision of material } \\
\text { supply, terms or clauses regarding } \\
\text { the material being outside of } \\
\text { specification or non-delivery and } \\
\text { any associated remittances would } \\
\text { be covered by this requirement. }\end{array}$ \\
\hline $\begin{array}{l}\text { 3. To provide } \\
\text { material reliably } \\
\text { and within the } \\
\text { quality } \\
\text { specification } \\
\text { required }\end{array}$ & $\begin{array}{l}\text { Financial groups and project } \\
\text { partners/investors; } \\
\text { Developers/Operators }\end{array}$ & $\begin{array}{l}\text { The supplier should be able to show } \\
\text { evidence that they are likely to be } \\
\text { able to provide a reliable and } \\
\text { quality consistent supply of } \\
\text { materials. This is separate to the } \\
\text { contractual agreement. }\end{array}$ \\
\hline $\begin{array}{l}\text { 4. The supply of } \\
\text { materials should } \\
\text { have a low } \\
\text { environmental } \\
\text { impact }\end{array}$ & $\begin{array}{l}\text { Environmental groups; } \\
\text { Developers/Operators; } \\
\text { National government and } \\
\text { policy makers; Local } \\
\text { government; } \\
\text { Community/public }\end{array}$ & $\begin{array}{l}\text { The supply of biomass material } \\
\text { should have a low or positive } \\
\text { impact upon the environment. }\end{array}$ \\
\hline $\begin{array}{l}\text { 5. To be financially } \\
\text { credible }\end{array}$ & $\begin{array}{l}\text { Financial groups and project } \\
\text { partners/investors; } \\
\text { Developers/Operators; } \\
\text { National government and } \\
\text { policy makers }\end{array}$ & $\begin{array}{l}\text { The supplier should be able to } \\
\text { demonstrate that they are } \\
\text { financially secure and credible if } \\
\text { they were to be required to produce } \\
\text { evidence for finance purposes. }\end{array}$ \\
\hline $\begin{array}{l}\text { 6. The supply of } \\
\text { materials should } \\
\text { have a positive } \\
\text { social impact }\end{array}$ & $\begin{array}{l}\text { National government and } \\
\text { policy makers; Local } \\
\text { government }\end{array}$ & $\begin{array}{l}\text { To satisfy this requirement the } \\
\text { engagement of a particular supplier } \\
\text { should lead to the stimulation of } \\
\text { positive social impacts for instance } \\
\text { job creation and poverty reduction. }\end{array}$ \\
\hline $\begin{array}{l}\text { 7. National energy } \\
\text { security should be } \\
\text { improved }\end{array}$ & $\begin{array}{l}\text { National government and } \\
\text { policy makers }\end{array}$ & $\begin{array}{l}\text { National governments have a } \\
\text { responsibility to ensure that the } \\
\text { energy being delivered to the nation } \\
\text { is secure to allow the continuation } \\
\text { of society and economy. }\end{array}$ \\
\hline
\end{tabular}


Table 6

House of Quality 1.

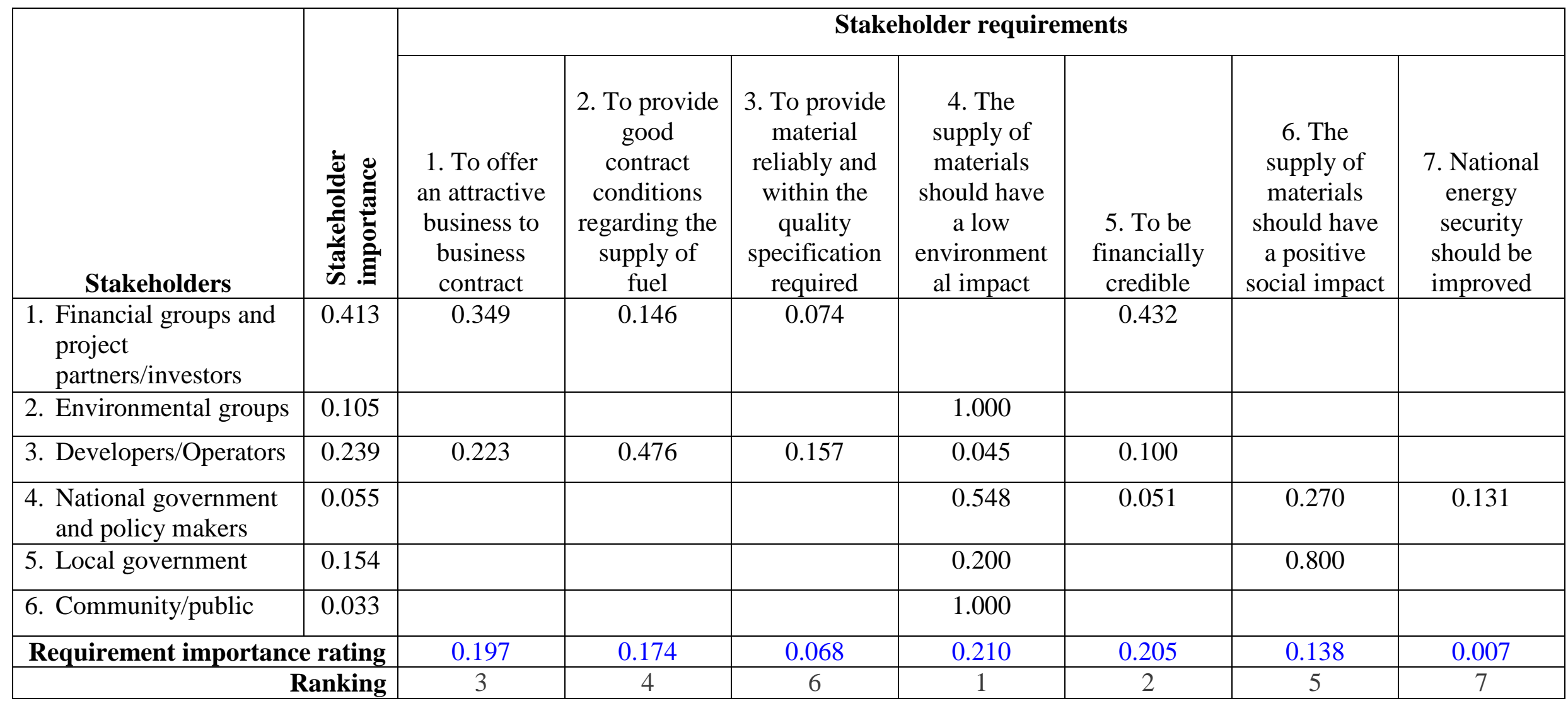


Table 7

28 Evaluating criteria and their identifying sources.

\begin{tabular}{|c|c|c|c|c|c|c|c|c|}
\hline & Evaluating criteria & 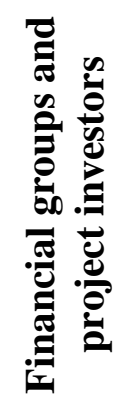 & 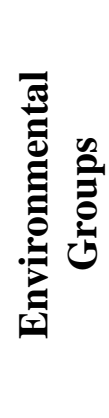 & 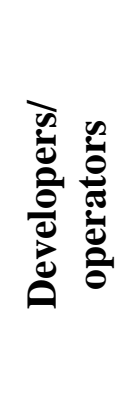 & 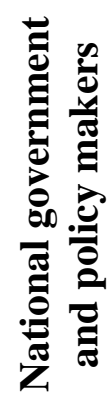 & 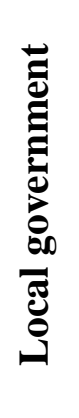 & 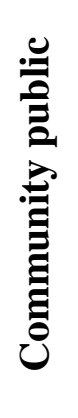 & Literature sources \\
\hline \multirow[t]{4}{*}{$\begin{array}{l}\text { Bioenergy } \\
\text { literature } \\
\text { review }\end{array}$} & $\begin{array}{c}\mathrm{CO}_{2} \text { (equivalent) emissions per } \\
\mathrm{MWh}\end{array}$ & $\checkmark$ & $\checkmark$ & $\checkmark$ & $\checkmark$ & $\checkmark$ & $\checkmark$ & $\begin{array}{l}\text { Afgan and Carvalho, 2003; Begić and } \\
\text { Afgan, 2007; Madlener et al., 2007; } \\
\text { Upham and Speakman, 2007; Zhou et al., } \\
\text { 2007; Beck et al., 2008; BTG, 2008; } \\
\text { Karagiannidis et al., 2009; Terrados et al., } \\
\text { 2009; Kaya and Kahraman, 2010; } \\
\text { Jovanovic et al., 2011; van Dam and } \\
\text { Junginger, } 2011\end{array}$ \\
\hline & Land use change & & $\checkmark$ & & $\checkmark$ & & & BTG, 2008 \\
\hline & Rural jobs created or safeguarded & & & & $\checkmark$ & & & $\begin{array}{l}\text { Haralambopoulos and Polatidis, 2003; } \\
\text { Ayoub et al., 2007; Longden et al., 2007; } \\
\text { Madlener et al., 2007; Upham and } \\
\text { Speakman, 2007; Buchholz et al., } 2009\end{array}$ \\
\hline & Base cost of material ( $£ /$ MWh) & $\checkmark$ & & $\checkmark$ & & & & $\begin{array}{l}\text { Longden et al., 2007; Buchholz et al., } \\
\text { 2009; Karagiannidis et al., 2009; Kaya anc } \\
\text { Kahraman, } 2010\end{array}$ \\
\hline
\end{tabular}




\begin{tabular}{|c|c|c|c|c|c|c|}
\hline \multirow{6}{*}{$\begin{array}{l}\text { Supply } \\
\text { chain } \\
\text { literature } \\
\text { review }\end{array}$} & Dependency on imports & $\checkmark$ & $\checkmark$ & $\checkmark$ & $\checkmark$ & $\begin{array}{l}\text { Madlener et al., 2007; Buchholz et al., } \\
\text { 2009; van Dam and Junginger, } 2011\end{array}$ \\
\hline & Visibility of supply chain & $\checkmark$ & & $\checkmark$ & & $\begin{array}{l}\text { Madlener et al., 2007; Buchholz et al., } \\
\text { 2009; van Dam and Junginger, } 2011\end{array}$ \\
\hline & Distance from customer & $\checkmark$ & & & & $\begin{array}{l}\text { Braglia and Petroni, 2000; Liu et al., 2000; } \\
\text { Perçin, 2006; Sarkar and Mohapatra, } \\
\text { 2006; Yang and Chen, 2006; Gencer and } \\
\text { Gürpinar, 2007; Hou and Su, 2007; } \\
\text { Sevkli et al., 2007; Ng, } 2008\end{array}$ \\
\hline & $\begin{array}{l}\text { Ease of communication/ personal } \\
\text { relationship }\end{array}$ & & & $\checkmark$ & & $\begin{array}{l}\text { Sarkis and Talluri, 2002; Chen et al., } \\
\text { 2006; Perçin, } 2006\end{array}$ \\
\hline & Track record & $\checkmark$ & & $\checkmark$ & & $\begin{array}{c}\text { Çebi and Bayraktar, 2003; Chan, 2003; } \\
\text { Chen and Huang, 2007; Gencer and } \\
\text { Gürpinar, } 2007\end{array}$ \\
\hline & $\begin{array}{l}\text { Quality control process and } \\
\text { mechanisms in place }\end{array}$ & & & $\checkmark$ & & $\begin{array}{l}\text { Narasimhan et al., 2001; Choy and Lee, } \\
\text { 2002; Talluri and Narasimhan, 2004; } \\
\text { Sarkar and Mohapatra, 2006; Chan et al., } \\
\text { 2007; Gencer and Gürpinar, 2007; Sevkli } \\
\text { et al., } 2007\end{array}$ \\
\hline
\end{tabular}




\begin{tabular}{|c|c|c|c|c|c|}
\hline & Credit strength & $\checkmark$ & & $\checkmark$ & $\begin{array}{l}\text { Braglia and Petroni, 2000; Muralidharan et } \\
\text { al., 2002; Barla, 2003; Çebi and Bayraktar, } \\
\text { 2003; Chan, 2003; Kahraman et al., 2003; } \\
\text { Choy and Lee, 2003; Wang et al., 2004, } \\
\text { 2005; Choy et al., 2005; Liu and Hai, } \\
\text { 2005; Bayazit, 2006; Bevilacqua et al., } \\
\text { 2006; Chen et al., 2006; Perçin, 2006; } \\
\text { Sarkar and Mohapatra, 2006; Yang and } \\
\text { Chen, 2006; Chan et al., 2007; Chen and } \\
\text { Huang, 2007; Gencer and Gürpinar, 2007; } \\
\text { Huang and Keskar, 2007; Wu et al., 2007; } \\
\text { Bottani and Rizzi, } 2008\end{array}$ \\
\hline & Size of balance sheet & $\checkmark$ & & $\checkmark$ & \multirow{2}{*}{$\begin{array}{l}\text { Braglia and Petroni, 2000; Muralidharan et } \\
\text { al., 2002; Barla, 2003; Çebi and Bayraktar, } \\
\text { 2003; Chan, 2003; Kahraman et al., 2003; } \\
\text { Choy and Lee, 2003; Wang et al., 2004, } \\
\text { 2005; Choy et al., 2005; Liu and Hai, } \\
\text { 2005; Bayazit, 2006; Bevilacqua et al., } \\
\text { 2006; Chen et al., 2006; Perçin, 2006; } \\
\text { Sarkar and Mohapatra, 2006; Yang and } \\
\text { Chen, 2006; Chan et al., 2007; Chen and } \\
\text { Huang, 2007; Gencer and Gürpinar, 2007; } \\
\text { Huang and Keskar, 2007; Wu et al., 2007; } \\
\text { Bottani and Rizzi, } 2008\end{array}$} \\
\hline & $\begin{array}{l}\text { Financially robust and credible } \\
\text { counterparty }\end{array}$ & $\checkmark$ & & $\checkmark$ & \\
\hline \multirow{2}{*}{$\begin{array}{c}\text { Criteria } \\
\text { from } \\
\text { interviews }\end{array}$} & $\begin{array}{c}\text { Performance against EU } \\
\text { sustainability assurance standards }\end{array}$ & & $\checkmark$ & $\checkmark$ & \\
\hline & Long term contract available & $\checkmark$ & & $\checkmark$ & \\
\hline
\end{tabular}




\begin{tabular}{|c|c|c|c|c|c|c|l|l|}
\hline Take or pay clause conditions & $\checkmark$ & $\checkmark$ & $\checkmark$ & & & & \\
\hline & Traceable (chain of custody) & $\checkmark$ & & $\checkmark$ & & & & \\
\hline Public finance imitative (PFI) & $\checkmark$ & & & & & & \\
\hline backing & Fixed price (or known escalator) & $\checkmark$ & & $\checkmark$ & & & & \\
\hline & Clear definition of material & & $\checkmark$ & & & & $\checkmark$ & \\
\hline Guarantee of fuel quality available & & & $\checkmark$ & & & & \\
\hline $\begin{array}{c}\text { Supplier stability within bioenergy } \\
\text { market }\end{array}$ & $\checkmark$ & & $\checkmark$ & & & & \\
\hline & FSC accreditation (FSC, 2012) & & $\checkmark$ & $\checkmark$ & $\checkmark$ & & & \\
\hline $\begin{array}{c}\text { Alternative end use (best use of } \\
\text { biomass) }\end{array}$ & & $\checkmark$ & & & & & \\
\hline & Diversion of material from landfill & & $\checkmark$ & & $\checkmark$ & & & \\
\hline $\begin{array}{c}\text { Environmental regulatory } \\
\text { environment within which the } \\
\text { supplier operates }\end{array}$ & $\checkmark$ & $\checkmark$ & $\checkmark$ & & & & \\
\hline $\begin{array}{c}\text { Biodiversity change } \\
\text { Small and medium enterprise } \\
\text { (SME) employment created }\end{array}$ & & & & & $\checkmark$ & $\checkmark$ & & \\
\hline
\end{tabular}




\section{Table 8}

Requirements and corresponding evaluating criteria.

\begin{tabular}{|c|c|}
\hline Requirements & Relevant evaluating criteria \\
\hline $\begin{array}{l}\text { 1. To offer an attractive business to } \\
\text { business contract relations }\end{array}$ & $\begin{array}{l}\text { Long term contracts; Take or pay clauses; Track record; Personal relationship/ease of } \\
\text { communication }\end{array}$ \\
\hline $\begin{array}{l}\text { 2. To provide good contract conditions } \\
\text { regarding the supply of fuel }\end{array}$ & $\begin{array}{l}\text { Contract has PFI back up; Fixed price; Base cost of material (£/MWh); Clear definition of } \\
\text { fuel; Guarantee of fuel quality available }\end{array}$ \\
\hline $\begin{array}{l}\text { 3. To provide material reliably and within } \\
\text { the quality specification required }\end{array}$ & $\begin{array}{l}\text { Traceable (chain of custody); Visibility; Quality control mechanisms in place; Guarantee of } \\
\text { fuel quality available; Supplier stability (in biomass market); Dependency on imports }\end{array}$ \\
\hline $\begin{array}{l}\text { 4. The supply of materials should have a } \\
\text { low environmental impact }\end{array}$ & $\begin{array}{l}\mathrm{CO}_{2} \text { /MWh; Land use change; FSC accreditation; Alternative end use (best use of biomass); } \\
\text { Diversion of material from landfill; Environmental regulatory environment in which the } \\
\text { supplier operates; Performance against sustainability assurance certificate indicators; } \\
\text { Biodiversity change }\end{array}$ \\
\hline 5. To be financially credible & Credit strength; Size of balance sheet; Financially robust or credible counterparty \\
\hline $\begin{array}{l}\text { 6. The supply of materials should have a } \\
\text { positive social impact }\end{array}$ & Rural jobs created or safeguarded; SME employment created \\
\hline $\begin{array}{l}\text { 7. National energy security should be } \\
\text { improved }\end{array}$ & Long term contracts; visibility; Distance from buyer; Dependency on imports \\
\hline
\end{tabular}


Table 9

House of Quality 2.

\begin{tabular}{|c|c|c|c|c|c|c|c|c|}
\hline \multirow[b]{2}{*}{ Stakeholder requirements } & \multirow{2}{*}{ 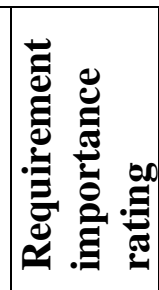 } & \multicolumn{7}{|c|}{ Evaluating criteria } \\
\hline & & $\begin{array}{l}\text { 1. Long } \\
\text { term } \\
\text { contracts }\end{array}$ & $\begin{array}{l}\text { 2. Take or } \\
\text { pay clauses }\end{array}$ & $\begin{array}{l}\text { 3. Track } \\
\text { record }\end{array}$ & $\begin{array}{l}\text { 4. Personal } \\
\text { relationship }\end{array}$ & $\begin{array}{l}\text { 5. Contract } \\
\text { has PFI } \\
\text { back up }\end{array}$ & $\begin{array}{l}\text { 6. Fixed } \\
\text { price }\end{array}$ & $\begin{array}{c}7 . \\
\text { Traceable } \\
\text { (chain of } \\
\text { custody) }\end{array}$ \\
\hline $\begin{array}{l}\text { 1. To offer an attractive business } \\
\text { to business contract relations }\end{array}$ & 0.197 & 0.112 & 0.271 & 0.554 & 0.063 & & & \\
\hline $\begin{array}{l}\text { 2. To provide good contract } \\
\text { conditions regarding the supply } \\
\text { of fuel }\end{array}$ & 0.174 & & & & & 0.075 & 0.327 & \\
\hline $\begin{array}{l}\text { 3. To provide material reliably and } \\
\text { within the quality specification } \\
\text { required }\end{array}$ & 0.068 & & & & & & & 0.252 \\
\hline $\begin{array}{l}\text { 4. The supply of materials should } \\
\text { have a low environmental } \\
\text { impact }\end{array}$ & 0.210 & & & & & & & \\
\hline 5. To be financially credible & 0.205 & & & & & & & \\
\hline $\begin{array}{l}\text { 6. The supply of materials should } \\
\text { have a positive social impact }\end{array}$ & 0.138 & & & & & & & \\
\hline $\begin{array}{l}\text { 7. National energy security should } \\
\text { be improved }\end{array}$ & 0.007 & 0.056 & & & & & & \\
\hline \multicolumn{2}{|c|}{ Evaluating criteria importance rating } & 0.022 & 0.053 & 0.109 & 0.012 & 0.013 & 0.057 & 0.017 \\
\hline & Ranking & 13 & 7 & 2 & 20 & 18 & 6 & 14 \\
\hline
\end{tabular}


Table 10

House of Quality 2 (continue).

\begin{tabular}{|c|c|c|c|c|c|c|c|c|}
\hline \multirow[b]{2}{*}{ Stakeholder requirements } & \multirow[b]{2}{*}{ 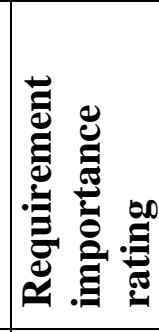 } & \multicolumn{7}{|c|}{ Evaluating criteria } \\
\hline & & $\begin{array}{l}\text { 8. Base } \\
\text { cost of } \\
\text { material } \\
(£ / \mathrm{MWh})\end{array}$ & $\begin{array}{l}\text { 9. Clear } \\
\text { definition } \\
\text { of fuel }\end{array}$ & $\begin{array}{c}10 . \\
\text { Visibility }\end{array}$ & $\begin{array}{l}\text { 11. Quality } \\
\text { control } \\
\text { mechanisms } \\
\text { in place }\end{array}$ & $\begin{array}{c}12 . \\
\text { Guarantee } \\
\text { of fuel } \\
\text { quality } \\
\text { available }\end{array}$ & $\begin{array}{c}13 . \\
\text { Supplier } \\
\text { stability (in } \\
\text { biomass } \\
\text { market) }\end{array}$ & $\begin{array}{l}14 . \\
\text { Distance } \\
\text { from } \\
\text { buyer }\end{array}$ \\
\hline $\begin{array}{l}\text { 1. To offer an attractive business } \\
\text { to business contract relations }\end{array}$ & 0.197 & & & & & & & \\
\hline $\begin{array}{l}\text { 2. To provide good contract } \\
\text { conditions regarding the supply } \\
\text { of fuel }\end{array}$ & 0.174 & 0.392 & 0.056 & & & 0.150 & & \\
\hline $\begin{array}{l}\text { 3. To provide material reliably and } \\
\text { within the quality specification } \\
\text { required }\end{array}$ & 0.068 & & & 0.167 & 0.051 & 0.397 & 0.090 & \\
\hline $\begin{array}{l}\text { 4. The supply of materials should } \\
\text { have a low environmental } \\
\text { impact }\end{array}$ & 0.210 & & & & & & & \\
\hline 5. To be financially credible & 0.205 & & & & & & & \\
\hline $\begin{array}{l}\text { 6. The supply of materials should } \\
\text { have a positive social impact }\end{array}$ & 0.138 & & & & & & & \\
\hline $\begin{array}{l}\text { 7. National energy security should } \\
\text { be improved }\end{array}$ & 0.007 & & & 0.295 & & & & 0.110 \\
\hline \multicolumn{2}{|c|}{ Evaluating criteria importance rating } & 0.068 & 0.010 & 0.013 & 0.003 & 0.053 & 0.006 & 0.001 \\
\hline \multicolumn{2}{|c|}{ Ranking } & 5 & 22 & 18 & 27 & 7 & 25 & 28 \\
\hline
\end{tabular}


Table 11

House of Quality 2 (continue).

\begin{tabular}{|c|c|c|c|c|c|c|c|c|}
\hline \multirow[b]{2}{*}{ Stakeholder requirements } & \multirow[b]{2}{*}{ 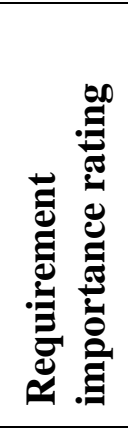 } & \multicolumn{7}{|c|}{ Evaluating criteria } \\
\hline & & $\begin{array}{c}15 . \\
\mathrm{CO}_{2} / \\
\mathrm{MWh}\end{array}$ & $\begin{array}{l}\text { 16. Land } \\
\text { use } \\
\text { change }\end{array}$ & $\begin{array}{c}\text { 17. FSC } \\
\text { accreditation }\end{array}$ & $\begin{array}{c}18 . \\
\text { Alternative } \\
\text { end use } \\
\text { (best use of } \\
\text { biomass) }\end{array}$ & $\begin{array}{c}19 . \\
\text { Diversion } \\
\text { of material } \\
\text { from } \\
\text { landfill } \\
\end{array}$ & $\begin{array}{c}20 . \\
\text { Environment } \\
\text { al regulatory } \\
\text { environment } \\
\text { in which the } \\
\text { supplier } \\
\text { operates } \\
\end{array}$ & $\begin{array}{c}21 . \\
\text { Performance } \\
\text { against } \\
\text { sustainability } \\
\text { assurance } \\
\text { certificate } \\
\text { indicators } \\
\end{array}$ \\
\hline $\begin{array}{l}\text { 1. To offer an attractive business } \\
\text { to business contract relations }\end{array}$ & 0.197 & & & & & & & \\
\hline $\begin{array}{l}\text { 2. To provide good contract } \\
\text { conditions regarding the supply } \\
\text { of fuel }\end{array}$ & 0.174 & & & & & & & \\
\hline $\begin{array}{l}\text { 3. To provide material reliably and } \\
\text { within the quality specification } \\
\text { required }\end{array}$ & 0.068 & & & & & & & \\
\hline $\begin{array}{l}\text { 4. The supply of materials should } \\
\text { have a low environmental } \\
\text { impact }\end{array}$ & 0.210 & 0.376 & 0.159 & 0.056 & 0.083 & 0.199 & 0.033 & 0.070 \\
\hline 5. To be financially credible & 0.205 & & & & & & & \\
\hline $\begin{array}{l}\text { 6. The supply of materials should } \\
\text { have a positive social impact }\end{array}$ & 0.138 & & & & & & & \\
\hline $\begin{array}{l}\text { 7. National energy security should } \\
\text { be improved }\end{array}$ & 0.007 & & & & & & & \\
\hline \multicolumn{2}{|c|}{ Evaluating criteria importance rating } & 0.079 & 0.033 & 0.012 & 0.017 & 0.042 & 0.007 & 0.015 \\
\hline \multicolumn{2}{|c|}{ Ranking } & 4 & 12 & 20 & 14 & 10 & 23 & 17 \\
\hline
\end{tabular}


Table 12

House of Quality 2 (continue).

\begin{tabular}{|c|c|c|c|c|c|c|c|c|}
\hline \multirow[b]{2}{*}{ Stakeholder requirements } & \multirow[b]{2}{*}{ 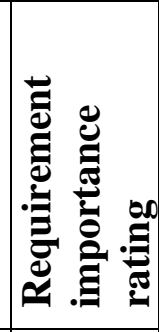 } & \multicolumn{7}{|c|}{ Evaluating criteria } \\
\hline & & $\begin{array}{l}22 . \\
\text { Credit } \\
\text { strength }\end{array}$ & $\begin{array}{l}\text { 23. Size } \\
\text { of } \\
\text { balance } \\
\text { sheet }\end{array}$ & $\begin{array}{c}24 . \\
\text { Financially } \\
\text { robust or } \\
\text { credible } \\
\text { counterparty }\end{array}$ & $\begin{array}{c}\text { 25. Rural } \\
\text { jobs created } \\
\text { or } \\
\text { safeguarded }\end{array}$ & $\begin{array}{c}26 . \\
\text { Dependency } \\
\text { on imports }\end{array}$ & $\begin{array}{l}\text { 27. SME } \\
\text { employment } \\
\text { created }\end{array}$ & $\begin{array}{l}28 . \\
\text { Biodiversity } \\
\text { change }\end{array}$ \\
\hline $\begin{array}{l}\text { 1. To offer an attractive business } \\
\text { to business contract relations }\end{array}$ & 0.197 & & & & & & & \\
\hline $\begin{array}{l}\text { 2. To provide good contract } \\
\text { conditions regarding the supply } \\
\text { of fuel }\end{array}$ & 0.174 & & & & & & & \\
\hline $\begin{array}{l}\text { 3. To provide material reliably and } \\
\text { within the quality specification } \\
\text { required }\end{array}$ & 0.068 & & & & & 0.042 & & \\
\hline $\begin{array}{l}\text { 4. The supply of materials should } \\
\text { have a low environmental } \\
\text { impact }\end{array}$ & 0.210 & & & & & & & 0.025 \\
\hline 5. To be financially credible & 0.205 & 0.193 & 0.083 & 0.724 & & & & \\
\hline $\begin{array}{l}\text { 6. The supply of materials should } \\
\text { have a positive social impact }\end{array}$ & 0.138 & & & & 0.667 & & 0.333 & \\
\hline $\begin{array}{l}\text { 7. National energy security should } \\
\text { be improved }\end{array}$ & 0.007 & & & & & 0.539 & & \\
\hline \multicolumn{2}{|c|}{ Evaluating criteria importance rating } & 0.040 & 0.017 & 0.148 & 0.092 & 0.007 & 0.046 & 0.005 \\
\hline \multicolumn{2}{|c|}{ Ranking } & 11 & 14 & 1 & 3 & 23 & 9 & 26 \\
\hline
\end{tabular}


Table 13

Ten most and least important evaluating criteria.

\begin{tabular}{|c|c|c|c|}
\hline $\begin{array}{l}\text { Top } 10 \text { evaluating } \\
\text { criteria }\end{array}$ & $\begin{array}{l}\text { Importance } \\
\text { rating }\end{array}$ & $\begin{array}{l}\text { Lowest } 10 \text { evaluating } \\
\text { criteria }\end{array}$ & $\begin{array}{l}\text { Importance } \\
\text { rating }\end{array}$ \\
\hline $\begin{array}{l}\text { 1. Financially robust or } \\
\text { credible counterparty }\end{array}$ & 0.148 & 1. Distance from buyer & 0.001 \\
\hline 2. Track record & 0.109 & $\begin{array}{l}\text { 2. Quality control } \\
\text { mechanisms in place }\end{array}$ & 0.003 \\
\hline $\begin{array}{l}\text { 3. Rural jobs created or } \\
\text { safeguarded }\end{array}$ & 0.092 & 3. Biodiversity change & 0.005 \\
\hline 4. $\mathrm{CO}_{2} / \mathrm{MWh}$ & 0.079 & $\begin{array}{l}\text { 4. Supplier stability (in } \\
\text { biomass market) }\end{array}$ & 0.006 \\
\hline $\begin{array}{l}\text { 5. Base cost of material } \\
(£ / \mathrm{MWh})\end{array}$ & 0.068 & $\begin{array}{l}\text { 5. Environmental } \\
\text { regulatory environment in } \\
\text { which the supplier } \\
\text { operates }\end{array}$ & 0.007 \\
\hline 6. Fixed price & 0.057 & 5. Dependency on imports & 0.007 \\
\hline 7. Take or pay clauses & 0.053 & 7. Clear definition of fuel & 0.010 \\
\hline $\begin{array}{l}\text { 7. Guarantee of fuel } \\
\text { quality available }\end{array}$ & 0.053 & 8. FSC accreditation & 0.012 \\
\hline $\begin{array}{l}\text { 9. SME employment } \\
\text { created }\end{array}$ & 0.046 & 8. Personal relationship & 0.012 \\
\hline \multirow[t]{2}{*}{$\begin{array}{l}\text { 10. Diversion of material } \\
\text { from landfill }\end{array}$} & 0.042 & $\begin{array}{l}\text { 10. Contract has PFI back } \\
\text { up }\end{array}$ & 0.013 \\
\hline & & 10. Visibility & 0.013 \\
\hline
\end{tabular}




\section{University Library}

\section{- M M I E R R V A gateway to Melbourne's research publications}

Minerva Access is the Institutional Repository of The University of Melbourne

Author/s:

Scott, JA;Ho, W;Dey, PK

Title:

Strategic sourcing in the UK bioenergy industry

Date:

2013-12-01

Citation:

Scott, J. A., Ho, W. \& Dey, P. K. (2013). Strategic sourcing in the UK bioenergy industry.

INTERNATIONAL JOURNAL OF PRODUCTION ECONOMICS, 146 (2), pp.478-490. https:// doi.org/10.1016/j.ijpe.2013.01.027.

Persistent Link:

http://hdl.handle.net/11343/118656 